\title{
Historical Notes
}

\section{Ambergris in Perfumery in the Past and Present Indian Context and the Western World*}

\author{
T M Srinivasan**
}

(Received 11 September 2014; revised 31 December 2014)

\begin{abstract}
The extracts of plants, flowers and animal products are often known to have been used by human beings to fragrant their bodies from time immemorial. In India, ambara or amber as a perfume or an aromatic ingredient is found mentioned in the Sanskrit Lexicons. Among the animal products, ambergris is supposed to be a secretion from the sperm whale, used in perfumery as a fixative or as a tincture in deluxe perfumes, possibly brought to India by the Arabs. The Travels of Marco Polo (c. 1300 AD) provides interesting account about the hunting of whales for ambergris and oil and also the methods adopted by the whale hunters. A narrative on ambergris and its connection to India is well known. In India, Ambergis is used in perfumes and drugs in Ayurveda and Unani system of medicine. It was also not free from adulteration as reported by Abu'l Fazal (c.1550-1602 AD) in his work, $\bar{A}$ 'in $i$-Akbarí.
\end{abstract}

The fanciful myths of Arab travellers about the formation or the origin of ambergris got new interpretation through the intensive researches of European and Japanese scholars in the 18th and 19th centuries. According to Victor Hassalauer (as quoted by William A Paucher, 1959), ambergris is a calculus formed in the hind gut of the sperm whale by the residues of juice of the bile or of the stomach with the blood, often found with the excrements of the animal. It is perhaps caused due to internal irritation created by horny beaks of Cephalopods like squids, cuttlefish and octopus.

Pure ambergris is a wax-like substance insoluble in water, but soluble in alcohol, chloroform, ether and certain volatile and fixed oils. The light grades of ambergris, white in colour, are usually the best and it is these grades that go to make tincture or the concentrated (absolute). Among the several components isolated from ambergris, the main three are: triterpene alcohol ambrein, epicoprostanol and coprostanone, the first being the principal active ingredient. It is an excellent fixative and used as matured tincture in high class perfumery for long durability of odour.

The objective of this paper is to trace the origin and features of ambergris and how it has become world class aromatic product because of its commercial value.

Key words: Ambergris, Chemical constituents, Composition of Ambergris, Different names, Formation of ambergris, Myth and reality, Odour, Physical properties, Sperm whale, Substitutes, Travelers' account (Arab and European), Uses

\section{INTRODUCTION}

Since the very early times the aromatic products from the vegetable kingdom as well as the animal kingdom attracted the attention of the ancients. While the plants offer a wide range of sweet-smelling fragrant perfumes, the animal kingdom on the other hand contains absolutely no substance that may be called sweet-scented in the

\footnotetext{
* The author dedicates this small note with all humility in fond memory of his mentor (Late) Dr. N.K. Panikkar, FNASc, FNA, and Founder-Director, National Institute of Oceanography, Dona Paula, Goa, on his birth centenary year 2013.

**Assistant Director (Retd.) CSIR-Indian Institute of Chemical Technology, Hyderabad- 500007, email: ramatms@yahoo.com
} 
strict sense of the term. However, there are a few animal (terrestrial and marine) secretions and excretions that are used in perfumery as an excellent means for fixing suitable vegetable odours. Admittedly, they are mostly malodorous, and in some cases extremely offensive. Nevertheless, there are four substances of animal origin that are widely employed in perfumery, namely, Castoreum, Civet, Musk and Ambergris. Of these, the Castoreum and the Civet find a much wider application in perfumery and drugs; whereas the Musk and the Ambergris, very expensive in the market in pure form, are consequently used in deluxe or high-class perfumes. In the following pages an attempt is made to present a brief account against an historical backdrop about the commercial value of ambergris, its origin, physical properties, main chemical constituents, ambergris substitutes and uses as a world-class aromatic product.

\section{Historical Gleanings}

Ambergris occupies a rather unique or unequalled place in the history of perfumery. It has its own peculiar properties that have been noticed since the Biblical times. It was unknown to the Greeks and Romans; but, according to Paulus Aegineta, it was made known to pharmacy by the Arabs as anbar in other neighboring countries.

According to P. K. Gode, the history of Indian cosmetics and perfumery has not been critically reconstructed though material for historical studies are found in abundance in several Sanskrit and Prakrit texts. Fortunately he has published some interesting papers based on two treatises on Gandha Śästra (Science of cosmetics and perfumery) (Journal of the University of Bombay, September 1945, pp. 44-45; New Indian Antiquary, Vol. VII, 1945, pp. 185-193.). Gode says that Muni Punyavijayaji, a learned Jain scholar from Ahmedabad, had raised a pertinent query regarding an aromatic ingredient. This Jain Muni says that Malayagiri, a Jain commentator of the $12^{\text {th }}$ century $A D$, mentions in his work a perfume or aromatic ingredient of the name ambara along with aguru (aloe wood), karpura (camphor), etc. burnt to produce fragrant smoke. Now we come to know that in the past ambara was used as the incense (Gode, 1949, p. 51). References to ambara as a perfume are found mentioned only in Sanskrit or Prakrit literature. In the earlier Sanskrit lexicon, 'Amara Kośa', written and complied between $500 \mathrm{AD}$ and 800, records the term ambara to denote the sky, but not as a perfume (Gode, 1949, p. 51). However, P.K. Gode has thoroughly scanned all the available Sanskrit Lexicons (Kośas) and chronologically arranged all of them and given the reference and meaning of ambara and the same is reproduced here (Gode, 1949, p. 52):

\begin{tabular}{|c|c|c|}
\hline Chronology & Lexicon & $\begin{array}{l}\text { Reference } \\
\text { Ambara is called }\end{array}$ \\
\hline Bet. 900 & Sasvata-kośa & Sugandhi-dravya \\
\hline$\& 1000$ & Trikanda-kośa & Gandha-dravya \\
\hline $1111 \mathrm{AD}$ & Visva-kośa & Sugandhaka \\
\hline $\begin{array}{l}1100- \\
1200 \mathrm{AD}\end{array}$ & $\begin{array}{l}\text { Nanartharnava } \\
\text { Sankṣepa }\end{array}$ & Sugandhi-dravya \\
\hline C. 1250 & Medinī-kośa & Sugandhi \\
\hline $\begin{array}{l}\text { Bet. 1175- } \\
1434\end{array}$ & $\begin{array}{l}\text { Anekārtha- } \\
\text { tilaka }\end{array}$ & Surabhi-dravya \\
\hline $\begin{array}{l}\text { Bet. } 1300 \\
\& 1600\end{array}$ & $\begin{array}{l}\text { Viśvalocana- } \\
\text { kośa }\end{array}$ & Sugandhaka \\
\hline c. $1685 \mathrm{AD}$ & $\begin{array}{l}\text { Sabdaratna- } \\
\text { samanvaya- } \\
\text { kośa }\end{array}$ & Sugandhaka \\
\hline c. $1676 \mathrm{AD}$ & $\begin{array}{l}\text { Rajavyavatara- } \\
\text { kośa }\end{array}$ & $\begin{array}{l}\text { Matsyika (a product } \\
\text { from fish) and } \\
\text { included among } \\
\text { perfumes like musk, } \\
\text { etc. }\end{array}$ \\
\hline
\end{tabular}


In this context it is pertinent to note that ambergris is mentioned differently in Indian and other languages:- Sanskrit - ambaral, amber, sugandh; Hindi, Bengali, Marathi, Konkani amber; Gujarathi - ambara; Tamil - minumbar; Arabic-amber; Persian - musk amber; Singalese - mus sumbra; Burmese - payan-anbhat; and so on.(Nanda, 1926, p. 1072.). However, it may be mentioned here that there is no direct word to mean ambergris in Sanskrit lexicons compiled between $700 \mathrm{AD}$ and c. $1676 \mathrm{AD}$ by different scholars. In Latin ambergris is known as 'ambra grisea'; whereas in French and German languages it is known as 'ambergris' and 'ambra' respectively. In fact the name of the substance 'ambergris' is derived from the French 'ambre gris' (gray amber) to distinguish it from the fossilized resin or gum brown amber. Professor Dalgado observed that "perhaps the word amber is imported directly from Arabic" (Soares, 1936, p. 15.) He also points out that in many vernaculars in India the term 'amber' for 'ambergris' is still current. The reason, a plausible one, is that the Arabs were directly responsible for the introduction of this substance as anbar into India as one of the important commercial products probably in the $8^{\text {th }}$ or $9^{\text {th }}$ century AD. In India it was used as Sugandhadravya or Sugandhaka. It was also referred to as matsyika by virtue of the fact that this perfumery product is obtained from the entrails of the whales. (Bose, Sen, S.N., and Subbarayappa, B.V, 1968, p. 344.) Early Romans (Latin) called it ambarum. Some other nations and languages gave it the same name or one with very slight variations. Ambergris is often met with in the Indian bazaars in the form of special preparation known as abr-i-amber, amber or araba.

Aetzios of Amida (now Diarber) in Mesopotamia (c. 550 AD) was educated in Alexandria. He wrote a medical encyclopedia in 16 volumes. It was called Tetrabiblos.

In pharmacology, he introduced the medicinal use of clove, camphor, musk and ambergris (Partington, 1970, p. 201). Let us examine a few references to ambergris as found mentioned in the Arabic sources. A series of Arabian geographers and travelers accounts bring down to us the narrative on ambergris up to the $14^{\text {th }}$ century. Among them Yaqubi (c. 875 AD), Abu Zaid (Abu Zaidu-L-Hassan) of Siraf on the Persian Gulf (950 AD), Sulaiman of Basra, Al Masudi of Baghdad ( 956 AD), Al-Idrisi of Sicily (1099-1186 AD, and Ibn-Batuta (1325-54 AD) had passed on to us valuable information on the subject.

(1) The Arab geographer Yaqubi mentions in his work various kinds of anbar including anbar Hindi which is procured from the coast and then exported to Basara in the Persian Gulf. The anbar that comes from Hind is called karkpatus associated with a community of that name (Gode, 1970, p. 201).

(2) The second Arab geographer Abu Zaid of Siraf gives the details of the origin of anbar and describes some varieties which do not comprise any variety associated with 'Hind'. He further states that anbar is thrown up along the coast commencing from the sea of Hind; but it is not known from whence it comes (Abu Zaid, 1867-1887, pp. 1-11).

\footnotetext{
1 It appears that ambara was used to denote ambergris from late medieval period. Earlier the word agnijara was used for ambergris. It is mentioned as a desiccated jarāyu of an agninakra living in ocean. It is said to be helpful in the jāraṇa precess of mercury and to have many medicinal properties. Siddhabheșajamanimālā by Krṣnarāma of $19^{\text {th }}$ c. mentions ambara as a perfume and as a noteworthy medicinal drug. Monier William's Dictionary has the entry as ambara, am (i.e ambara and ambaram. Among other, it gives the meanings saffron and perfume, but with ambra in parenthesis after perfume. A very standard dictionary in Telugu script entitles 'Sarvaśabda sambodhinyakhyoyam samskrta nighantuh' compiled in 1875 by Paravastu Srinivasacharya has two entries ambarah (masculine) and ambaram (feminine) separately with the manning sugandhi for the word in masculine gender. Śivakośa has a reading 'ambaram sugandhikam' and the commentary Śivaprakāśa explains ambaram arthat sugandhikam gandhadravyam'(B Ramarao).
} 
(3) Abu Zaid's predecessor who recorded his notes towards the latter half of the $9^{\text {th }}$ century (c. $851 \mathrm{AD}$ ) has often been identified with the merchant/traveller Sulaiman of Basra who seems, however, to have been only one of the sources of information commanded by that unknown writer. Sulaiman tells us that "ambergris is found in the Sea of Harkand (Bay of Bengal) during the south-west monsoon, and a small quantity of it is bartered for iron by the natives of Lanjabatus islands (Nicobar)" (Sulaiman, p.10; Abu Zaid, p. 93.). This particular information is confirmed nearly seven centuries later by the Portuguese Durate Barbosa who states that "in the island of Nauacar (Nicobar) there is very good ambergris which is conveyed to Malacca and other places" (Dames, 1918-1921, Vol. I, p.56; Vol. II, pp. 40, 77 , 107)

(4) The account of Al-Masudi of Baghdad (890$956 \mathrm{AD})$ is quite interesting in this context. He says that anbar grows at the bottom of the sea of Harkand. "It is white, black and of dark gray colour". "The best ambergris is found on the islands and coasts of the Seas of Zinj (Eastern Africa); it is round, of a pale blue, and sometimes as big as an ostrich egg. These morsels which have been swallowed by the fish called 'Awal'. When the sea is agitated it casts up fragments of anbar almost like lumps of rock, and the fish swallowing these is choked thereby, and floats on the surface. The men of Zinj, or wherever it be, then come in their canoes, and fall on the creature with harpoons and cables, draws it ashore, cut it up, and extract the ambergris" (Nainar,1942, pp.187-190.).

(5) Here is an account of the Sicilian geographer, Al-Idrisi (1099-1186 AD). He records that anbar (ambergris) is found on the shores of Yemen flung there by the waves after stormy tempests. He further states that Harun-alRashid, the Caliph, had sent some persons to enquire from the shore-dwellers what they knew about ambergris as there were many tales then current about its origin. The result of their enquiry was that ambergris flows from springs at the bottom of the sea (Howe, 1946, p. 103; Gode, 1949, p. 55.). This traditional myth about the origin of ambergris was passed on from one generation to another in order to perpetuate the beliefs into reality.

(6) The last and perhaps the most important Arabic account comes from the indefatigable Moorish (born in Tangier, Morocco) traveller and chronicler, Ibn Batuta (1325-54 AD). He spent many years in India visiting places and recording his observations. In his 'Travels', Batuta, while describing his voyage to Ma'bar (Coromandel coast) and his escape from a shipwreck, records that "The sailors tied ropes to the raft and swam with their aid. I sent along with them all things that I valued and the jewels and ambergris and they reached the shore in safety because the wind was in their favour (Gibb, 1939, p. 261)

Abu'l-Fazl Allami (1551-1602) was a versatile genius, and in his famous classic ' $\bar{A}$ ' $i n$ iAkbarī' (Chronicles of Akbar) gives considerable attention to ambar. In it he draws our attention to several theories about the origin of ambergris: "Some say that ambar grows at the bottom of the sea and that it is the food brought up again after eating, by various animals living in the sea. Others say that fishes eat it and die from it, and that it is taken from the intestines. According to some, it is the dung of the sea cow called 'sara'; or the foam of the sea. Others again say it trickles from the mountain of islands. Many look upon it as marine gum; others whose opinion the author adopt, take it to wax. It is said that on some mountains a great deal of honey is to be found, so much in fact that runs into the sea; the wax rises to the surface when the heat of the sun reduces it to a solid state. As the bees collect the honey from sweet smelling flowers, ambar is naturally, scented. Bees are also 
occasionally found in it. Abu Sina thinks that there is a fountain at the bottom of the sea, from which ambar rills, when it is carried by waves to the shore. Ambar, when fresh, is moist; the heat of the sun causes it dry up. It is of various colours: the white is the best, and the black is the worst; the middling sort is pistachio-coloured and yellow. The best kind goes by the name Ashhab. It feels greasy, and consists of layers. If you break it looks yellowish white. The whiter, lighter, and more flexible it is better. Next quality is the pistachio coloured 'ambar; and the inferior to it the yellow kind, called Khash Kshashi. The black kind is bad; it is inflammable" (Blochmann, 1965, p. 83). It is interesting to note here that $\mathrm{Abu}$ ' 1 -Fazl has given a list of perfumes and their prices and the chief among them is Ambar-i-ashhb (Ambergris perfume) and the cost of ambergris perfume (Ambar-i-ashhab) mentioned in his work is ' 1 to 3 Muhurs per tola'(Blochmann, 1965, p. 80). Another perfume mentioned in the list is Ambari-Ladan and is priced 11/2 to 4 R., per Ser. "Ladan is often called Ambar; but this has nothing to do with Ambergris. It is taken from a tree which grows in the confines of Qibous (Cyprus) and Qisus (Chios) or Qistus" (Blochmann, 1965, p. 83).

We shall now turn our attention to one of the most celebrated European travellers' accounts about ambergris. Marco Polo was the Venetian traveller and geographer in the $13^{\text {th }}$ century, and the 'prince of medieval travellers', whose travels brought a new epoch in the direct contacts between Europe and the East. Compiled by Polo in 1298, the chronicle 'The Travels of Marco Polo' describes his travels across the entire continent of Asia and provides the only comprehensive travelogue of a European traveller in the East in the middle ages. In this monumental work Marco Polo makes the following personal observations about ambergris: "Traders resorting to the 'Island of Males and Females' with the principal object to 'purchase ambergris of which a quantity is collected there" (Yule, 1903, p. 424). While describing the island of Socotra (near Cape Guardafui, the north-Eastern point of the continent of Africa) he makes the following noteworthy points: (1) Ambergris is found on the coasts. It is "voided from the entrails of whales" (Yule, 1903, pp. 425-426). (2) It is an article of merchandise in great demand. (3) The inhabitants make it a business to kill the whales with harpoons and drag them ashore and "extract the ambergris from the bellies and from their head they procure casks of (spermaceti) oil" (Yule (Tr. \& Ed.), 1903, pp. 425426). (4) Ships bound for Aden halt at Socotra and purchase ambergris and cotton goods. (5) "There is also much ambergris from the whales; and as the tide throws it on the coasts (of Madagascar), it is collected for sale" (Yule, 1903, p. 428). Many trading ships visited the island of Zanzibar (on the East African coast) and bartered their goods for ambergris gathered on the coasts where it was found in quantities as the sea abounds in whales (Yule, 1903, pp. 406 \& 433; Smethurst, 2005 , pp. $361 \& 308$ ). In the same work we notice that the Nicobar islands are also believed to be Lanjabatus or Lankhabatus of the old Arab navigators. The natives always parted ambergris and coconuts for iron. Being an article of merchandise in great demand, they make it a business to take these fish; and this they do by means of a barbed iron, which they strike into the whale so firmly that it cannot be drawn out. To the iron (harpoon) a long line is fastened, with a buoy at the end, for the purpose of discovering the place where the fish, when dead, is to be found. They then drag it to the shore, and proceed to extract the ambergris from its belly, whilst from its head they procure several casks of (spermaceti) oil (Yule, 1903, p. 406). This is a brief account by Marco Polo on the hunting of whales for ambergris and oil and it also brings to light the methods adopted and the contrivances used by the whale hunters in medieval times.

Entries in the Chinese annals written during the middle ages clearly show that the 
Chinese merchants visited South India on a number of occasions. In the first quarter of the $15^{\text {th }}$ century the third emperor of the Ming dynasty sent out a series of naval expeditions to establish contacts with many lands, including South India. No fewer than seven of these expeditions reached South India under the command of Cheng (Zheng) Ho. In one of these expeditions Fei Hsin and Ma Huan accompanied him and the former two travellers had left behind the accounts of different countries they visited (Sastri, 1955, p.28). Fei Hsin in his 'Hsing-ch'a-sheng-Len': 'The Overall Survey of the Star Raft' (1436 AD) speaks of a Lung-yerhsii or 'Ambergris Island' near the point of Aschin, North West Sumatra, where large quantities of ambergris were collected and brought for sale in the market of Su-men-ta-la (Sumatra city) (Hsin). The Chinese Ming history also confirms that ambergris was one among many articles sent as tribute by Sumatra. From these Chinese records it is noticed that the north coast of Sumatra was a busy centre in ambergris in medieval times. Malacca (Malay-Penang peninsula) also had a share in this trade later on.

The Chinese text 'Pents'an' mentions ambergris under the name hung sien hiang (dragon's saliva perfume) and describes it as a sweet-scented product, which is obtained from the south western seas. It is greasy, and at first yellowish white, when dry, it forms pieces of a yellowish black colour. In spring the whole herds of dragons swim in that sea, and vomit it out. Others say it is formed in the belly of a large fish (Yule, 1903, p. 408). "Ambergris, which itself has, when pure, a faintly aromatic smell, has always been greatly valued by perfumers because of its remarkable power of fixing for months delicate floral and other scents and giving a special velvety quality to them. For this reason it was called in Chinese 'tzu shao hua', though there was a transliteration, 'a mo hsiang', evidently derived from Arabic 'al-ambar'. The commonest name was 'hung-sien hiang' (dragon spittle); but 'tiaoching' (whale semen) was also current” (Needam, 1974, p. 142, $)^{2}$.

Let us turn our attention again to the European travelers' accounts. The Frenchman F. Bernier who travelled in India from 1656 to 1668 notes in his 'Travels' that India imports ambergris in large quantities from the Maldives and Mozambique (Bernier, 1934). In the second half of $17^{\text {th }}$ century (1676) Jean Baptiste Tavernier, another French traveler and a diamond expert, records some valuable information on both amber and ambergris. " (1) we do not know how it is formed or where it is found; (2) It is found in the seas of the East and sometimes on the English and European coasts; (3) Large quantity of it is found on the coast of Melinda (an Arab town on the east coast of Africa), and especially at the mouth of the river Rio di sena (the Zambezi), (4) the Governor of Mozambique brings with him to Goa every three years ambergris worth 3,00,000 pardos (=30,000 pounds)" (Tavernier, Jean-Baptise, William Crooke(Ed.), V. Ball (Tr.), 1925, pp. 138142). " "The Governor of Mozambique trades with Negroes who inhabit the length of Melinde and they generally barter for goods which they require with ivory or ambergris" (Tavernier, 1925, pp. 109 \&153).

Towards the second quarter of the $16^{\text {th }}$ century, Garcia da Orta, a Portuguese physician

\footnotetext{
2 For the History of knowledge of ambergris in China, see E.H. Schafer-The Golden Peaches of Samarkand: A Study of Thang Exotics, Uni. of California Press, Berkeley and L and A, 1963, p. 174; Yamada Kentaro-A short History of Ambergris (and its trading) by the Arabs and the Chinese in the Indian Ocean, Kinki Uni. 1955, 1956, Reports of the Institute of World Economic, KKD, Nos. 8 and 11

3 In this work the French traveller devotes three pages to a story of a Frenchman, Marin Renaud of Orleans on board a Portuguese vessel sailing from Goa to Manilas in 1627 AD. This Frenchman discovered a piece of ambergris on the shore near the mouth of a river while bathing there. This piece weighed 33 livres. The sailors and soldiers quarreled for its possession. The captain of the ship presented it to the king of Portugal through the Viceroy and thus settled the dispute tactfully
} 
and botanist, came to India in 1534. In Goa he had a garden which he nursed and studied a number of medicinal plants. He published his findings in 1565 in the form of a monograph titled 'Coloquios des Simples e drogas cousso medicinalis da India compostos pelle'(Colloquies on the Simples and Drugs of India) in which he made a special mention about ambergris as one of the drugs. In a chapter exclusively devoted to ambergris he tells us of ambergris containing beaks of birds (de Orta, 1913). On the other hand the Portuguese Duarte Barbosa gives a new version about the origin of ambergris. He says that 'ambergris is the guano of birds (the dung of sea birds) which has been swallowed and voided by whales' (Dames, Vol. I, p.56 \&Vol. II, pp. 40, 77 $\&$ 107). Francois Pyrard de Laval (ca 1578-1623), who served the government of his country as a soldier in Goa in 1608-10, says that in the Maldives the ambergris called 'gomen' when prepared 'meccuare, thrown upon the coast formed part of the king's revenue' (Gray, 1887, p 229).

In the 'Memoirs' of the Mogul Emperor Jahangir (1643) we notice that ambergris was directly employed without any admixture with other aromatic ingredients to perfume the throne. Here goes the description: "The legs and body of the throne were at the same time loaded with 50 manus of ambergris so that wherever it might be found expedient to put it together, no further perfumes were necessary, for an assemblage of whatever magnitude" (Price, 1918, pp. 2-3).

A.C. Sterling in collaboration with William A. Poucher contributed the following account: 'In the first half of the $16^{\text {th }}$ century Leo Africanus records, amongst others, the following gifts made by the Sultan of Fez to mountain chief: fifteen men slaves and fifteen women slaves, sixteen civet-cats, one pound of civet and one pound of amber (ambergris)' (Bovill, 1959, p.26).

In his account of India John Marshall (1668-72 AD) refers to ambergris found at Mauritius and Johanna, and says "What? This is hath not beene perfectly knowne" (That this has not yet been perfectly known) (John Marshall in India, 1927, pp. 48 and 415). John Fryer (16721681 AD) in his account of the East India and Persia clearly mentions ambergris as a precious article of trade within the charter of the East India Company and rightly observes that "gray ambergris is the best and that it yields a fragrant odour and feels in substance like bees wax" (Fryer, 1909-1915, p.142).

Whitelaw Ainslie in his compendium Materia Indica (1826) informs us that " $\mathrm{Mr}$ Magellan, on the authority of M. Aublet, author of the 'Histoire dela Guyana', published in 1774, mentions undoubtedly vegetable ambergris gathered from a tree which grows in Guyana, and there called Cuma; it is of a whitish brown colour, with a yellowish tinge, melts and burns like a wax in the fire, but is rather of a more powdery consistence than the common ambergris" (Ainslie, 1826). But this description of "vegetable ambergris' has nothing to do with the marine animal product.

Ambergris had been the subject of seafaring tales and cruising captains' dream throughout the medieval period. At a later date the aroma of ambergris caught the imagination of the poets and writers of standing who made a specific reference to it in their works. In one of the Portuguese poems 'The Lusiads', we come across a poignant reference to amber (ambergris). The lines are as follows:

$$
\begin{aligned}
& \text { "On Africa's strand..... } \\
& \text { From calls unknown, here bounteous } \\
& \text { ocean pours } \\
& \text { The fragrant amber on to sandy shore" } \\
& \text { (Lisbon, 1572, p. 103) }
\end{aligned}
$$

John Milton in his famous poetry 'Paradise Regained' alludes to ambergris as 'grisamber'(Milton, p. ii, 11. 337).

In one of the records of the Dutch East India Company regarding the trade contacts with 
the coastal rulers on the Malabar Coast, it is mentioned that the Dutch merchant Pieter Sijbrant Goroes (July 9, 1643) brought from Malabar 236,584 lbs. of pepper, $181 / 2$ ounces of ambergris and 3,043 lbs. of dry ginger for 493,704 guilders (unit of money of Netherlands) from the Zamorin, chief of Calicut. According to the agreement reached between the Dutch company and the Zamorin, the latter owed to the company 106197 lbs. of pepper or 2351683 guilders (Poonam, 1948). This agreement do not throw light on information regarding the break up of individual items and the value of ambergris in particular.

Like the Andaman Islands, the existence of the Nicobar Islands had been known from the time of Ptolemy onwards. But unlike the Andaman Islands, there is a long history of European occupation of the Nicobar Islands and other parts of the Eastern seas. The staple article as well as in barter deals the Nicobar inhabitants since the time of Danes (1756) was calible, birds' nests, split cane, betel nuts, ambergris and tortoise shell among other things (Imperial Gazetteer of India, 1908). From these historical gleanings cited above we gather that ambergris was the prized commodity for trade. And it was the Arabs who held monopoly over the selling of this substance in India and other adjacent areas for long.

\section{Ambergris: Myth and Reality}

Throughout the early and medieval periods, ambergris was considered as an important prized commodity for trade and barter dealings. It was the Arab seafarers who first noticed the importance of ambergris and held the monopoly over the substance for trade purposes. They were responsible for the introduction of this marine aromatic substance in India and other contiguous or adjacent countries. And thus the substance became the sellers' market. So it will be of interest to note briefly the following fabulous and imaginary or fanciful views expressed by the early writers as to the actual origin of ambergris.
One of the earliest myths is that the Greeks believed that ambergris came from springs in or near the sea. Al Masudi (950 AD) mentions in his work that ambergris "grows in the bottom of the sea of Harkand" (Nainar, 1942, pp.187-190). Al Edrisi (1165 AD) reports that ambergris "flows from the springs at the bottom of the sea" (Howe, 1946, p. 103; Gode, p. 55). Abu'l-Fazl 'Allami recounts in his work several theories about the origin of ambergris based on several popular beliefs and versions. "According to some, it is the dung of the sea cow called 'sara' or the foam of sea. Others again say it trickles from the mountains of islands. Many look upon it as marine gum; others whose opinion the author adopt, take it to be wax. It is said that on some mountains a great deal of honey is to be found, so much in fact that it runs into the sea; the wax rises to the surface, when the heat of the sun reduces it to a solid state. As the bees collect the honey from sweet smelling flowers, Ambar is, naturally, scented. Bees are also occasionally found in it. Abu Sina thinks that there is a fountain at the bottom of the sea, from which Ambar rills, when it is carried by waves to the shore" (Blochmann,1965, p. 83). The Chinese texts mention the substance under the name hung sien hiang (dragon's saliva perfume), hung-hsien hsiang (dragon's spittle), tiao ching (whale semen) and so on (Polo, 1903, p. 408; Needam, 1974, p. 142 , ). The Portuguese Duarte Barbosa surmises that "ambergris is the guano of birds (the dung of the sea birds) which has been swallowed and voided by whales" (Dames, 1918-1921, Vol. I, p.56 and Vol. II, pp. 40, $77 \&$ 107).

Erbest J. Parry cites in his work an early writer named Klobus, amongst others, the following views which have been entertained as to the origin of ambergris:- "(1) It was believed to be the excrement of a bird, common in Madagascar, melted by the sun's heat, washed out to sea, swallowed by a whale, and passed through its body unaltered. (2) Others believed it to be excrement material of certain cretaceous animals. 
(3) It was surmised to be a wax or gum exuding from certain trees growing on the sea shore, which dropped into the sea, congealed, and so became ambergris. (4) A common idea in the Orient is that it sprang from the bed of the sea as naphtha does from the earth, or that it was a kind of bitumen gradually working up from the ocean and hardening in the sun. (5) By some it was held to be a kind of marine fungus torn up from the bottom of the sea by violent tempests. (6) The origin of ambergris was also ascribed to honeycombs that had fallen into the sea from where the bees had built their nests. (7) Dr. Boylston and Mr. Dudley (Phil. Trans. 385, 387) asserted that ambergris was an animal concretion found in balls in the body of the male sperm whale. (8) A certain Herr Neumann, chemist to the King of Prussia (Phil. Trans. 433, 434, 435), denied that ambergris was an animal product at all, and that, if it were found in whales, it must have been swallowed by them. His own opinion was that it was a species of bitumen exuding from the earth into the sea. An old scientific work of $18^{\text {th }}$ century states: "The pieces are frequently seen composed of strata....with stones and bodies enclosed within, and the strata are sometime full of little shells....whence it may be conjectured that the ambergris had originally been in fluid state.... and enveloped such bodies as happened to be in its" (Parry, 1925, p. 36). These are some of the fabulous views expressed by the travellers and the literates and compiled by Klobius and reproduced by E.J. Parry on the origin of ambergris.

But Marco Polo was the first European traveller and chronicler who observed whales on the island of Socotra in the Indian Ocean and attributed ambergris to sperm whale which voided it from the intestinal track. "In 1783 the great botanist Joseph Banks presented a paper by Dr. Franz Xavier Schwediawer, a German physician living in London at the time, before the Royal Society which ended, forever, the Western confusion over ambergris and its origins. It correctly identified ambergris as a production of the often morbidly distended gut of sick sperm whales and associated its production with the beaks of the whale's principal foods, squid and cuttlefish" (Ambergris-Path finder-summary).

\section{Formation of Ambergris}

During the intensive scientific research on ambergris by the Western/European researchers/ scientists it was a debated point whether ambergris was a normal or pathological substance and whether it was released during the life or after the death of the sperm whale. One popular opinion is that it is an excretion from the whale. Other putative or reputed view is that "ambergris is a morbid secretion in the intestines of the Cachalot, deriving its origin either from stomach or binary ducts, and allied in its nature to gall-stones. While the masses found floating on the sea are those that have been voided by the whales, or liberated from the dead animal by the process of putrefaction" (Poucher, 1959, p. 29). It is generally believed that the formation of ambergris in the gut of the sperm whale is attributed to a secretion produced in response to the constant irritation caused by the sharp beaks of squids and cuttlefish and the indigestible parts, or perhaps is produced simply as a means of protection against the damage caused by them, and is periodically excreted. In his monumental work 'Cyclopedia of Perfumery' Erbest J. Parry reports that "some excellent work on the formation of ambergris was commenced by Beuregard. He separated an organism which he called Spirillus recti physeteris, from the intestines of the animal which appears to be responsible for slowly attacking the faecal matter and thus contributing to the formation of the calculus (Parry, 1925, p. 37). His premature death stopped this promising investigation. Victor Hasslauer is acknowledged as the greatest authorities on the subject. His account as reproduced by William A. Poucher is as follows: "Ambergris is from every evidence a calculus 
formed in the sperm whale by the residues of digestion amalgamate with the juice of the bile or of the stomach, with the blood, and often found with the excrements of the animal. The formation in question found in the interior of the animal gives a quality of amber different from that which is expelled by the animal. The sperm whale is a migratory animal going from place to place to find food-according to the seasons - currents which cause him to make a voyage which one can nearly call a circuit of the world. The animal furnishes a different (type of) amber, according to the part of the world in which he has been captured, or according to the spot where the amber has been found. This indicates clearly that the food absorbed by the whale influences the appearance, quality, and smell of the amber found" (Poucher, 1930, p. 24). But in reality ambergris is a waxy morbid secretion or concretion formed in the intestines or caecum of sick whales (Physeter macrocephalus $=$ Catodon . . The internal irritation is caused due mainly by the indigestible horny beaks of the Cephalopods like squids and cuttlefish and octopus on which the sperm whale voraciously feeds. The ill whale forms this substance known as 'calculus' which it can excrete or which may remain inside the whale and eventually cause its death. On some times, the whale manages to reject or eject the secreted substance and then recovers from his (pathological) disease; otherwise it dies. The dead body is eaten by other animals and the substance in the form of ambergris is liberated. Ambergris which has been expelled by the animal and exposed to the Sun for several years is certainly the best and of the finest quality. "The best sort is found floating in the sea or washed ashore; it has then had ample time to undergo its natural refining-process, probably on oxidation" (Poucher, 1930, p. 24). This may be one of the reasons that ambergris must have acquired a pleasant odour or a characteristic faintly earthy smell of its own.

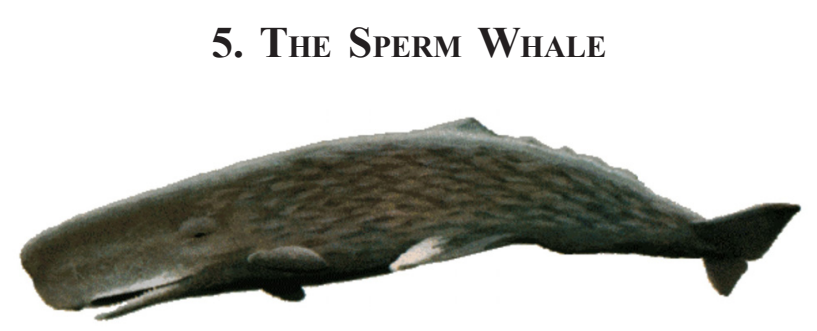

Fig. 1. The Sperm Whale

Whales are endangered species because the whale hunters often hunt them illegally for the meat and spermaceti oil; and the sperm whales are no exception in this regard. The sperm whale is a large or giant among the toothed whales with a massive square-shaped head containing a fluidfilled cavity; and it grows up to 60 or 70 feet long and has a square head and long projecting nose or nose and jaws (snout). Whale hunters in all regions hunt this particular marine animal, legally or illegally, primarily for the oil in its head, and for fat, spermaceti and ambergris. The sperm whale is reported to be a gregarious animal living in flocks and the males among them form harems. While the adult males may be found even in Polar region, females and young ones are restricted to warmer seas between $40 \mathrm{~N}$ and $\mathrm{S}$ latitudes. The pigmy sperm whale (Kogin breviceps), growing only to $3 \frac{1}{2}$ meters $(10-12$ feet), has a world wide distribution in tropical and temperate seas. It is occasionally found stranded on Indian shores. For centuries these pigmy sperm whales have been

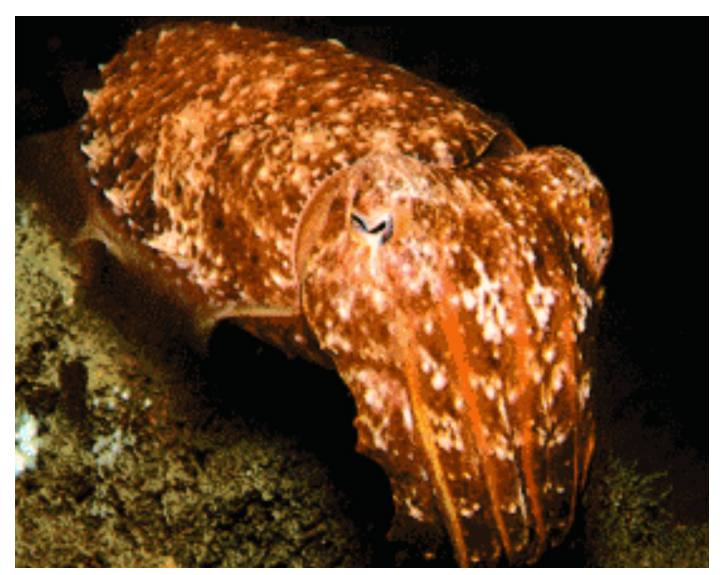

Fig. 2. Sepia officinalis L., The common cuttlefish 
hunted for the said reasons in every ocean as far as $60^{\circ} \mathrm{N}$ to $60^{\circ} \mathrm{S}$.

The staple food of these marine animals consists almost entirely of Cephalopods like the mollusks, squids and cuttlefish (Elledone moschata). To catch these speedy denizens of the depths the sperm whale dives deep and stays down for long periods. It is reported that a large sperm whale is submerged for 50 minutes of an hourlong diving cycle. A pertinent question arises in this context. Why should a sperm whale need to dive so deep? The reason is quite simple. Squids are found at all depths in every ocean. They are the principal food of many marine animals, sea birds including the Porpoises. "Perhaps the reason for the sperm whale diving behaviour is that the deeper the squid-eater can descend, the further it can out-distance its competitors and the greater the stocks of squids within its reach are. Certainly the sperm whale can catch deep-living squids that are beyond the reach of sea birds, seals or porpoises" (Malcohm 1979, pp. 128-141) ${ }^{4}$.

\section{Composition of Ambergris: Physical Properties}

Ambergris is a soft and fatty substance resembling bees wax. It is a concretion originating in the intestinal tract of the sperm whales. When cast out by these mammals, the substance is found as flotsams or on the seacoast as rounded lumps or dung. Fresh ambergris, whether extracted by the whalers or expelled by the whales, is soft and tar-like in consistency and with a disagreeable odour. Due to long exposure to air, sun and seawater, the substance undergoes certain transformation in its physical appearance and turns hard, its black colour fades to a lighter gray and it naturally develops and attains subtle and pleasing earthy smell or fragrance. This type of physical

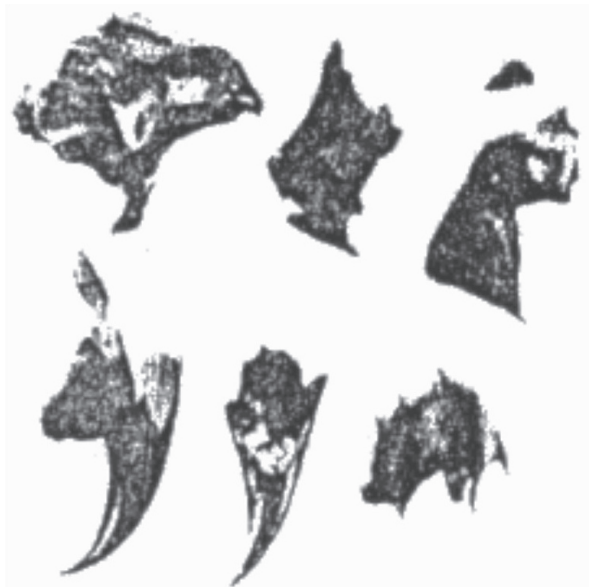

Fig. 3. Beaks of squid and cuttlefish from the gut of a sperm whale

changes may be due to oxidation and prolonged exposure to natural elements. But when found in the whale, dead or alive, the substance has a disagreeable and horrible smell. The lumps of ambergris are usually found embedded in the lower part of the intestine with the hard, parrotlike beaks of squids and cuttlefish on which the whale preys and feeds to a considerable extent; "and the generally accepted explanation of its formation is that it is a pathological growth caused by the irritation of these indigestive beaks in the whale's stomach" (Poucher, 1959, p. 27).

In the early part of the twentieth century no mention has been made in the literature of the different types of ambergris which was used in perfumery. However, William A Poucher in collaboration with A.C. Stirling (R.C. Treatt \& Co., Ltd.) was able to bring out a remarkable account of ambergris. His findings were primarily based on ten distinct types of ambergris samples (collected from New Zealand, North African coast, Gulf of Aden, Australia, Azores, Persian Gulf, Madagascar and all parts of world) from the work done in 1931 largely on the basis of colour, place of origin and odour (Poucher, 1959, p. 32).

\footnotetext{
${ }_{4}$ For further readings on whales see: (i) Herman Melville's Moby Dick: An Encyclopedia of Whales and Whaling; (ii) Scot Mc Vay, 'The Last of the Great Whales', Scientific American, August 1966, Vol. 215, No. 2, pp. 13-21; (iii) Raymond M Gilmore, 'The Return of the Grey Whales'. Scientific American, January 1955, Vol. 204; and (iv) Johan T. Ruud, Scientific American, December 1956, Volume 205).
} 
The light grades of ambergris are usually the best and it is these grades that go to make the tincture or the concentrated 'absolute' (complete). The colour and appearance of ambergris varies so widely that it is extremely very difficult for any one but an expert to identify it. "There is little doubt that Hasslauer is correct in stating that, owing to variations in food and temperature of the water, the quality varies according to the part of the world in which the sperm whale is living at the time of formation of the ambergris" (Poucher, p. 28; La Perfumerie Moderne, 1921, p. 56) Ambergris, white in colour, which has long been exposed to the sun and sea water, especially in the East, is considered the finest. It is comparatively rare and found only in small pieces, the largest recorded lump weighing only $20 \mathrm{oz} .^{5}$ Fine quality is usually silver-gray or pale golden in colour. The colour, however, ranges from reddish through dark gray and brown, sometimes mottled, to absolutely black. The black is the poorest and least valuable, as it is generally mixed with blood and faecal matter that gives it a strong and disagreeable odour. "The odour of ambergris is very characteristic but difficult to define; it has been described as 'musky', 'musty', 'earthy', but in the fine qualities, it is unpleasant and is reminiscent of the sea" (Poucher, 1959, p. 29).

Here are some of the important and conspicuous physical properties of ambergris. True ambergris is insoluble in water; but soluble in alcohol, chloroform, ether, fats and certain volatile and fixed oils. But it is relatively nonreactive to acid. It has a specific gravity ranging from 0.780 to 0.920 . Its melting point is between $60^{\circ} \mathrm{C}$ and $62^{\circ} \mathrm{C}$ and becomes a fatty yellow resinous liquid. It is melted by boiling water and volatilizes into a white vapour. A simple and effective critical test has been advocated by William A. Poucher to evaluate the true ambergris from the supposed ones. He says that "a hot needle should enter the mass easily without sticking, a characteristic odour should be given off, and an amber-coloured molten drop should appear on removing the point" (Poucher, 1959, p. 27). Based on various samples, H.I. Cole (1922) of the Bureau of Science, Manila, Philippine, devised a simple method for investigation and identification of 'supposed' and 'true' ambergris. "The former usually found floating far out at sea is shown not to be ambergris nor of animal origin, but most probably derived from a tree closely related to (latex from) Artocarpus elastica. Since true ambergris often contains the horny gills of a cuttlefish species a careful examination of substances thought to be ambergris will frequently be of greater value in the identification of this commodity than the ordinary physical and chemical methods" (Cole, 1922, p. 4009; Philippine J. of Science, 1922, pp. 105-109) ${ }^{6}$. So no chemical methods for the identification of "true" and "supposed" ambergris are to be found in the available literature. However, 'the Chinese test its purity by scraping it upon boiling tea, in which they consider it should dissolve.'(Parry, 1925, pp 36-40)

\section{Chemical Constituents}

In the past few centuries the Chemical Composition of ambergris was almost unknown. Very little was known until recently of the constituents of ambergris. Ambergris is composed of only a few characteristic chemical components or substances. These were identified and isolated at different point of time by individual or a group of researchers from Europe and Japan and made

\footnotetext{
5 The Hindu reported on February 28, 2013 that the "fishermen of the Chinnoor coastal village stumbled upon ambergris, weighing about $15 \mathrm{~kg}$, in the mid sea. According to Custom officials ambergris of such mass is a rare find in the region". According to Assistant Commissioner of Customs, the value of the ambergris is worth Rs.15 lakh - Rs.20 lakh in the Indian market and Rs.70 lakh - Rs.75 lakh in the international markets. The substance in possession and custody of Customs was yellowish.

${ }^{6}$ For details see Parry's Cyclopedia of Perfumery by Erbest J. Parry Vol. I, London, 1925, p. 36-40. Table on page 40 gives the details about the comparative statement of True Ambergris, Supposed Ambergris and Latex from Artocarpus elastica
} 
known to public. Here are some of the most important discoveries made by the eminent researchers. In 1820 two French pharmacists and chemists, Pierre-Joseph Pelletier and JosephBienaime Caventou, studied the composition of ambergris and isolated a colourless crystalline substance which they called 'ambrein'. They extracted the substance with alcohol together with some benzoic acid. In 1912, Riban found out that the substance was a mixture, but by repeated recrystallizations he isolated a pure body, for which he retained the name 'amberein', and which melts at $82 \mathrm{C}$ (Parry, 1925, pp. 36-39). After a gap of over a century Makoto Suzuki (1925) from Japan was the first researcher to prepare ambrein in a pure state (m. p. 83). In 1918 J. Lund made an ethereal extraction of ambergris, separating $26 \%$ of insoluble properties. J. Schmidt-Nielsen and A. Flood (1937) prepared the alcoholic resinoid. The insoluble fraction represented 1.5 to $5 \%$ of the raw material. "In 1946, two simultaneous publications established the chemical structure of this substance as being a tricyclic triterpene alcohol, $\mathrm{C}_{30} \mathrm{H}_{52} \mathrm{O}$, containing one tertiary hydroxyl group and two double bonds (Ruzicka and Lardon, Helv.Chim. Acta, 1946, 29, 912; Lederer, Marx, Mercier, and Perot, Loc.cit). Ambrein is thus the first tricyclic triterpene and a representative of the small group of animal tripenes." (Lederer, 1949, pp. 2123-2124; Lederer, 1949, p.7566)

After studying the chemistry of ambergris, Tony Burfield (2000) cites Dr. C. Sell's work (1990) and mentions that "ambergris contains 465 of cholesterol type of sterols including $(+)$-epicopriosterine and the triterpene alcohol (-)amberine (25-45\%), which is odourless, but this material is the precursor to other fragrant compounds formed by auto-oxidation, sunlight, and seawater such as (-)-gamma-cyclogeranyl chloride and (-)-gamma-bicyclohomofarnesal" (Sell, 1990, pp. 516-520; Burfield, 2005, p.2). The specific chemical constituents of ambergris, as mentioned by the renowned French chemist Edgar
Lederer in his article on the "chemistry and Biochemistry of some Mammalian Secretions and Excretions", are as follows (Lederer, 1949, pp. 2122):

\section{Constituents of Ambergris}

Ether-insoluble

$10-16 \%$

Cholesterol

$0.1 \%$

Pristane, $\mathrm{C}_{18} \mathrm{H}_{28}$ $2-4 \%$

Ketones (of which more than

$6-8 \%$

$50 \%$ are of coprostane-3-one)

Ambrein

$25-45 \%$

epiCoprosterol, free and esterified

$30-40 \%$

Free acids

$5 \%$

Coprosterol

$1-5 \%$

Esterified acids

$5-8 \%$

It is thus clear that the main chemical constituents of ambergris are ambrein, epiCoprosterol and Coprostanone.

Tony Burfield reports in 2005 "B.D. Mookherjee and R.R. Patel identified nearly 100 volatile substances in ambergris; they described some of the key components and their associated odours as follows: gamma-homocyclogeranyl chloride: ozony seawater, alpha-ambrinol: moldyanimal-faecal, g-dihydroionone: weak tobacco, gcoronal: sea-water, ambroxan: soft, creamy, persistent amber with velvety effect" (Burfield, 2005, p. 2).

\section{Ambergris Odour}

How does the ambergris acquire the peculiar odour? Jean gattefosse, in an article on ambergris (la Parfunerie Moderne, 1920, 259), opines that the odorous constituents of ambergris exist already or formed in certain cephalopods such as Elledone moschate, upon which the whale preys to a considerable extent. "In normal circumstances, these substances, as well as the crystalline ambrein, are expelled in the faeces. But if a whale be suffering from a certain micro- 
organic intestinal disease, these bodies are not expelled. The lumps of ambergris are then formed by the crystallization of the ambrein with other matter, as those substances not concerned in the formation of the calculi are consumed by the bacteria. The lumps are then expelled fortuitously or, if not, result in the animal's death" (Parry, 1925, p. 37).

G. Ohloff and his co-workers had carried out extensive studies on decalin ring compounds and the outcome is that there is a wealth of odour data for decalin compounds. His views on ambergris odour are as follows: "G. Ohloff is one of those who do not accept the full implication of the stereo-chemical hypothesis, even though he himself as confirmed the importance of certain stereo-chemical correlations. Thus, on the subject of decalin ring compounds with an ambergris odour, he writes that the "ambergris odour is composed of six distinguishable qualities. We have found that the characteristic ambergris odour or any of its individual component qualities arise exclusively in compounds having a decalin ring system of a strictly determined stereo chemistry" (Gustation and Olfaction Symposium, 1971, pp.178-183; Billot and Wells, 1975, p. 282).

Edgar Lederer gives a convincing views about the odour of ambergris. He says: "Perfumers will be interested to learn that probably the greater part of the odorous products of ambergris are oxidation products of ambrein and that the longlasting smell of ambergris may be partly explained by a constant autoxidation of ambrein with formation of volatile products. This oxidation is perhaps catalyzed by the appreciable amounts of copper contained in ambergris, which are derived from the haemocyanin of the blood of the cephalopods in the food of the sperm whale." (Lederer, 1949, p. 2125).

\section{Ambergris Tincture: Preparation}

In perfumery ambergris is usually used in the form of a tincture and on rare occasion as an infusion. In making various tinctures extracts it has been recommended by perfumers that the best results can be obtained by the use of the finest cologne spirits like the eau-de-cologne or lightly scented liquid. In other words, the finest quality of the alcohol used has an important influence on the finished deluxe perfume. Generally, the tincture /infusion from the dry plant material as well as the substances of animal origin are made by a simple process. The principal tinctures/ infusions from the above two sources are partially concentrated, while the others undergo a natural or accelerated process of aging. The tinctures are prepared by maceration (soften by soaking in alcohol), percolation or filtration or by dissolving the extracts in the alcohol. The concentration of the tinctures and infusions gives the ambergris resinoid. The yield of ambergris resinoids varies with the types of ambergris obtained from different sources. The yields are generally high, ranging from 80 to $90 \%$. Marcel Elliot and F.C Wells recommend that "The usual tincture of 2 to $3 \%$ concentration in $95 \%$ alcohol, the ambergris is pulverized for the purpose and allowed to remain in the solvent for a minimum period of three months, with constant stirring" (Elliot and Wells, 1975, p. 105). Y. R. Naves and G. Mazuyer of New York have conducted joint studies on Concretes, Resinoids, Floral oils and Pomades based on the natural perfume materials. They say, "Ultraviolet radiation, properly regulated, and used in an inert atmosphere, will ameliorate the odour of the tincture" (Naves and Mozuyer, 1947, p. 295).They emphasis that "The aging of the alcoholic tinctures and infusions is often extolled. It is accompanied by certain modifications of the perfumes, enhancing its qualities, making it more homogenous more mellowed. The phenomenon can be related to the process of alcoholysis, hydrolysis, esterification and acetalysation, and the bottles which contain the tinctures and infusions in dilute alcohol must be protected from the light, because the photolysis of glucocides, particularly in the case of Orris (violet-scented Iris root)". 


\section{Ambergris Substitutes (Natural and Synthetic)}

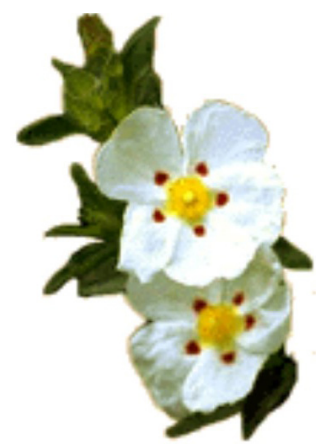

Fig. 4. Cistus ladanifer L. common rockrose

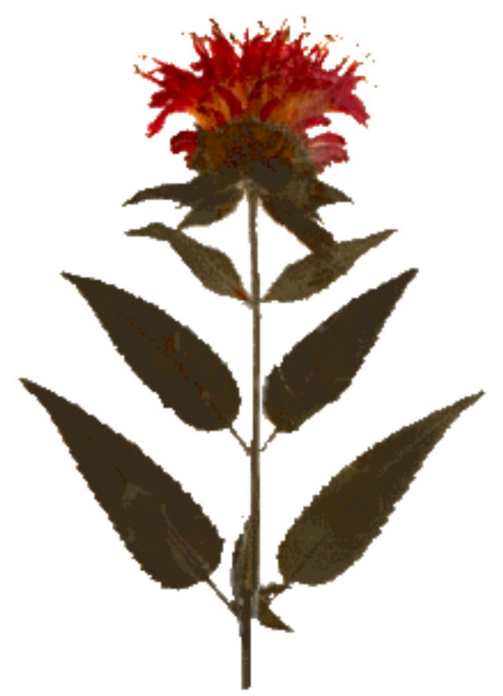

Fig. 5. Monarda didyma L. bee-balm

Is there a good substitute for ambergris? The answer is Yes and No. The natural substances extracted from the vegetable kingdom offered good results; but the synthetic chemicals proved to be harmful and useless. Here are a few examples.

In the past century a good number of research publications have been published on the various chemical compounds with a distinct ambergris-like odour. These compounds were ambergris substitutes. Such research works were ostensibly done with a view to reduce the cost of the ambergris extract or even the complete replacement of the genuine extract. They are all labdanoid terpenes which occur in a remarkable variety of plants, animals and microorganisms. These substitutes have some likeness to the ambergris odour. Many of these are based on labdanum - the oleo-resinous secretion from the leaves of several species of Cistus ladanifer L. a genus of the Rockrose family. These plants are widely distributed over the rocky grounds of the countries bordering the Mediterranean. The finest is obtained from plants growing in the Esterel the country lying to the west of Cannes on the French Riviera (Poucher, 1959, pp. 33-34).

\footnotetext{
"The odour of labdanum is probably the only one in the vegetable kingdom which closely approximates to that of ambergris, but the oil distilled from Monarda didyma L., by Schimmel \& Co., is also stated to resemble it. Bee-Balm is another natural substitute for ambergris. These botanical extracts are the base for fixtures, woody, sweet fragrances in the modern perfumery industry" (Poucher, 1959, p. 31).
}

William A. Poucher reports in his work that "artificial ambergris is now placed on the market and consists principally of the methyl ether of mono-nitro-dibromo-butyl-m-cresol" ${ }^{68} \mathrm{He}$ reports in his revised work that "Other artificial or synthetic or manmade chemical substances which were introduced into the market are methyl ethyl of mono-nitrodibromo-butyl-m-cresol, decahydro-B-naphthyldehyde, 5,6,7,8 tetrahydro-1naphthyl acetaldehyde and the ethyl ester of 24diisopropyl-glycidic acid. More recently a wellknown Swiss firm of Firmenich Laboratory have placed in the market Grisambrol, resulting from long and extensive research, and which its odour faithfully duplicates that of the original body, it possesses such power and persistence that minute quantities only are necessary in the majority of perfumes" (Poucher, 1930, p. 28).

Another important and useful substitute or artificial product discovered by the Firmenich Lab is Furon and commercially known as Fixateur 404. 
This product has all the odoriferous constituents of ambergris. A list of over forty chemicals with an ambergris odour has been published by Steffin Arctander in Perfumes and Flavour Chemicals (Arctander, 1969).

Steve Merti of Daily Brew (Sunday $8^{\text {th }}$ April, 2012) reports that the Canadian scientists of the University of British Columbia have discovered that balsam fir gene can be used to make a cheaper and more sustainable substitute that reduces the need for natural ambergris. Joerg Bohlmann, Professor of Botany, Forest Sciences (UBC) and Philipp Zerbe, a postdoctoral research associate, have published their findings in April 6 issue of the Journal of Biological chemistry. "We have now discovered that a gene from balsam fir is much more efficient at producing such natural compounds, which could make production of this bio-product less expensive and more suitable" said Prof. Bohlmann. But small companies continue to prefer and use natural ambergris for their products because the substitutes miss the complexity of natural smell of the odour it adds to perfumes, said Massimo Marcone, a Guelph University Professor of Food Sciences ( Merti, Steve, Daily Brew-Sunday, 2012). It may be added here that because of its prohibitive cost, Ambergris is almost nearly replaced by the synthetic molecule ambreina.

\section{Ambergris: Uses}

Known from the days of antiquity, ambergris was a valuable substance in the East as a perfume and drug. It was used and recommended by medieval apothecaries for its restorative powers and the perfumers for its fragrance. In modern times, it is chiefly used in the East to spice food preparation and wines, but in the West it is used in the manufacture of high-class perfumes. Since it has remarkable power of fixing a special velvety quality to deluxe perfumes, ambergris has been evaluated as a valuable substance by perfumers. In perfumery, ambergris is generally used in the form of a tincture, and on rare occasion an infusion and essence for fixing delicate odour.

In the early works on India by the foreigners we find the various uses of Ambergris. Whitelaw Ainslie (1826), Late of the Medical Staff of South India, mentions "In Hindoostan, Ambergris is chiefly used as a perfume; a drop or two of the essence mixed with a large quantity of lavender water, adding much to its fragrance." But Ainslie has not mentioned in his work the method of extracting the vital essence from Ambergris. He adds further that "Dr John Flemings (1810) in his Catalogue of the Indian Plants, however, tells us that the native physicians in Bengal consider the substance itself as aphrodisiac" (Ainslie, 1826).

However, ambergris, as a pheromone molecule, is traditionally used in India in Ayurveda and Unani systems of medicine as are used other pheromones such as musk deer, civet, and castoreum. The Indian Materia medica listed this wonderful substance as a stimulant and antispasmodic; it is used in treating general weakness, epilepsy, typhoid, fever, hysteria and other nervous disorders or afflictions. It is reported that the practitioners of the Ayurveda and Unani systems of medicine use and administer ambergris in combination with other medicinal herbs to treat the above-said ailments. The recommended dosage in the East, especially in India, is 5 to 15 grains (grain-a unit of weight, about $65 \mathrm{mg}$.). Even today, the practitioners of Indian system of medicine use the substance to treat the patients who suffer from the ailments as mentioned above. In confectionery ambergris is used as an additive and also as a flavouring agent in small qualities.

\section{Ambergris: Adultration}

Ambergris was not sold in the market in its pure form in the past as well as in the present day. It is interesting note that ambergris was adulterated even in the Mogul period. Here is a classic observation from Abu'l-Fazl. "Greedy 
bazaar dealers will mix it with wax, Mandal and Ladan, etc; but everyone has recourse to such practices. Mandal is a kind of ambar taken from the intestines of dead fishes; it does not smell much". "Ladan is also often called Ambar. It is taken from a tree which grows in the confines of Qibrus (Cyprus) and Qisus (Chios) Quistus" (Blochmann, 1965, p. 83). In the present time also it is liable to be adulterated with tallow, gum benzoin, olibanum, etc., by the unscrupulous dealers in perfumery products.

So, this is the story of Ambergris in perfumery expressed very briefly in a nutshell.

\section{ACKNowledgement}

The author is highly grateful to all the authors/scientists, whose monographs/articles cited in this 'Brief Note', had made him more knowledgeable. The author has downloaded five figures from the 'Ambergris Pathfinder: Summary' (http://www netstrider.com) and is grateful to the author of the said article.

\section{BIBLIOGRAPHY}

Abu'l-Fazali Allami. The Ain-I Akbari, Blochmann, H. (Tr.), First Edition, 1871, Second Edition, Goomer, S. L. (Ed), Delhi, 1965, pp. $80 \& 83$.

Ambergris-Path finder-summary: http://www.netsrider.com/ documents/ambergris/summary/index.html

Ainslie, Whitelaw, Materia Indica, Vol. I, London, 1826, Ch. ix.

Arctander, Steffin, Perfumes and Flavour Chemicals, 2 Volumes, 1969, Pennsylvania, USA.

Barbosa, Durate. A Book of Durate Barbosa, An account of the countries bordering on the Indian Ocean and their inhabitants, translated from the Portuguese by Mansel Longworth Dames, 2 vols. Hakluyt society, MCMXVIII-MCMXXI (1918-1921), Vol. II, p. 107; also Vol. I, p. 56; Vol. II, p. 40 and p.77.

Bernier, F. Travels in the Mogul Empire A.D. 1656-1668, London, 1934.

Billot, Marcel and Wells, F.V., Perfumery Technology: Art, Science and Industry, Ellis Hardwood Limited, England, 1975, pp. 105 \& 282.
Blochmann, H. (Tr.), The Ain-I Akbari by Abu'l-Fazali Allami, First Edition, 1871, Second Edition, Goomer, S. L. (Ed), Delhi, 1965, pp. $80 \& 83$.

Bose, D.M., Sen, S.N. and Subbarayappa, B.V. (Eds.) The Concise Book of History of Sciences in India, INSA, New Delhi, 1968, p. 344.

Bovill, E.B., Caravans of the Old Sahara.

Burfield, Tony. Modified Monograph, Natural Aromatic Materials-odours and Origins, Feb-Mar, 2005, pp. 2\&5, www.cropwatch.org

Clarke, Malcohm R. The Head of the Sperm Whale, Scientific American, 240.1 (Jan 1979): 128-141.

Cole, H.I. Identification of Ambergris, Chemical Abstracts, Vol. 16, 1922, p. 4009.

Dames, Mansel Longworth(Tr.). A Book of Durate Barbosa, An account of the countries bordering on the Indian Ocean and their inhabitants, Hakluyt society, MCMXVIII-MCMXXI (1918-1921), Vol. I, p. 56; Vol. II, pp. 40, 77, 107.

de Orta, Garcia. Colloquies on the Simples and Drugs of India, New Edition, Lisbon, 1895, Edited and annotated by Conde de Ficalho and translated into English from Portuguese with an introduction and index by Sir C. Markham, London, 1913.

Fryer, John. A New Account of the East India and Persia in Eight Letters, 1672-1681, Vol. 2, The Hakluyt Society, London, 1909-1915, p. 142.

Gibb, A. R. (Ed.). The Travels of Ibn Batuta, London, 1939, Chap. X, p. 261.

Gode, P.K. History of Ambergris in India between about A.D. 700 and 1900, CHEMIA, Annual Studies in the History of Chemistry,2(1949) 51 \& 52, 55, University of Pennsylvania, Philadelphia, 1949.

Gray, Albert (Tr.). The Voyage of Francois Pyrard of Laval to the East Indies, the Maldives, the Moluccas and Brazil (1607-1610), 1887, Vol.1, p. 229.

Howe, Sonia E. In Quest of Spices, London, 1946, p. 103.

Hsin, Fei. Hsing Ch'a Sheng Len: The Overall Survey of the Star Raft (South China and Maritime Asia)

Ibn Batuta. The Travels of Ibn Batuta, Gibb, A.R.(Ed.), London, 1939, Chap. X, p. 261.

Imperial Gazetteer of India, Vol. xix, Oxford, 1908.

Journal of the University of Bombay, September 1945, pp. 44-45. 
La Perfumerie Moderne, 1921, p. 56.

Lederer, Edgar, Chemistry and Biochemistry of some Mammalian Secretions and Excretions, Chemical Abstracts, 43(1949): 7566.

Lederer, Edgar, Chemistry and Biochemistry of some Mammalian Secretions and Excretions, Journal of the Chemical Society, III (1949): pp. 2122-2125.

Marco Polo. The Book of Ser Marco Polo -the Venetian concerning the kingdoms and Marvels of the East, Yule, Sir Henry (Tr \& Ed), London, 1903, Ch. XXXIV, pp. 424, 425-426, 428, 433; Chapter XXXII, pp. 406 \& 408 .

Merti, Steve, Daily Brew-Sunday, 8 April 2012; ca.news.yahoo.com/... Whale-barf-substitute-highend-perfumes.

Milton, John. Paradise Regained, p. ii, 1l. 337.

Nainar, S.M.H. Arab Geographers Knowledge of South India up to $14^{\text {th }}$ century A.D., Madras, 1942, pp.187190.

Nanda, K.M. Indian Materia Medica, Bombay, 1926, p. 1072.

Naves, Y.R. and Mozuyer, G. Natural Perfume MaterialsA Study of Concretes, Resinoids, Floral Oils and Pomades, New York, 1947, p. 295.

Needam, Joseph. Science and Civilization in China, 5(1974): 142, London.

New Indian Antiquary, Vol. VII, 1945, pp. 185-193.

Parry, Erbest J. Parry's Cyclopaedia of Perfumery, Vol. I, London, 1925, pp 36-40.

Partington, J.R. A History of Chemistry, London, 1(1970): 201.

Philippine J. of Science, 20(1922): 105-109

Poonam, T.J. A Survey of the Rise of the Dutch Power in Malabar (1603-1678), Trichinopoly, 1948.

Poucher, William A. Perfumes, Cosmetics and Soaps with special reference to synthesis, Vol. I., Third edition, London, 1930, pp. 24 \& 27-28.
Poucher, W. A. Perfumes, Cosmetics and Soaps with Special Reference to Synthetics, Vol. I, $6^{\text {th }}$ edition, London, 1959, pp. 26-29 and 31-34.

Price, Major David (Tr.). Memoirs of the Emperor Jahangir, Calcutta, 1918, pp. 2-3.

Pyrard, F., The Voyage of Francois Pyrard of Laval to the East Indies, the Maldives, the Moluccas and Brazil (1607-1610), Gray, Albert (Tr.), 1887, Vol.1, p. 229.

Relationship between odour, sensation and stereo-chemistry of Decalin Ring compounds, Gustation and Olfaction Symposium, 1970, Gustation and Olfaction, Academic Press, 1971, pp.178-183.

Sastri, K.A. Nilakanta. A History of South India, from Prehistoric Times to the fall of Vijayanagar, OUP, Madras, 1955, p.28.

Sell, C. The Chemistry of Ambergris, Chemistry \& Industry, 20(20 ${ }^{\text {th }}$ Sept 1990): 516-520.

Smethurst, Paul. The Travels of Marco Polo, The Barnes and Noble publishing Inc., U.S.A., 2005, Chap. XXXV, Foot Note 3, pp. 308 \& 361.

Soares, A. X.(Tr.) Portuguese Vocables in Asiatic Languages, Baroda Series, 1936, p. 15.

Sulaiman, Ancient Accounts of India and China by Two Mohammedan Travellers Who went to those parts in the $9^{\text {th }}$ Century, Rennaudot, Eusebius (Tr.), London, MDCCXXXIII; Vol. I, p.10.

Tavernier, Jean-Baptise. Travels in India, Crooke, William (Ed.), Ball, V. (Tr.) OUP, London, 1925, Vol. II, pp. 109, 138-142, 153.

Yule, Sir Henry (Tr \& Ed). The Book of Ser Marco Polothe Venetian concerning the kingdoms and Marvels of the East, , London, 1903, Ch. XXXIV, pp. 424, 425426, 428, 433; Chapter XXXII, pp. 406 \& 408.

Zaid, Abu. Ancient Accounts. The Second Account: or Discourse of Abu Zaid of Siraf, Vol. I. p. 93.

Zaid, Abu. History of India as told by its own Historians, The Muhammadan Period, Elliot, H.M. and Dawson, J. (Eds.), Vol. 1, pp. 1-11, London, 1867-1887. 